\title{
Mass-Elite Congruence and Representation in Argentina
}

Noam Lupu and Zach Warner

In representative democracies, policymakers should reflect the policy preferences of citizens (Manin 1997; Pitkin 1967). Scholars have long assumed that citizens elect representatives whose platforms are closest to their own preferences (e.g., Downs 1957). And models of accountability assume that elites have incentives not to stray too far from the preferences of sanctioning voters (e.g., Ferejohn 1986). But how close are politicians' preferences to those of their constituents? Do they indeed reflect an aggregation of citizens' preferences, or do they prioritize some citizens over others?

These questions are not merely empirical curiosities. If policymakers and policies do not reflect the preferences of citizens, a democratic system

For their comments and advice, we thank Larry Bartels, Daniel Buquet, Nick Carnes, Lucía Selios, Gabriel Vommaro, and participants at the workshop "Making Democracy Count" at the Universidad Diego Portales. All translations are our own.

N. Lupu

Vanderbilt University, Nashville, TN, USA

Z. Warner

University of Wisconsin-Madison, Madison, WI, USA

(C) The Author(s) 2017

A. Joignant et al. (eds.), Malaise in Representation in Latin

American Countries, DOI 10.1057/978-1-137-59955-1_12 
ought to hold them to account. In a properly functioning representative democracy, these should be off-equilibrium instances. Voters should quickly replace elites who are not representing their preferences with others who will. If, for some reason, they cannot do so, they may become disillusioned with democratic institutions, disaffected from politics, and disapproving of the political elite.

A growing body of studies has examined the congruence between citizens' preferences on the one hand and policymakers' views or policy outcomes on the other. ${ }^{1}$ At the most basic level, these studies have shown that mass-elite congruence varies across space and time-that is, that some governments more closely reflect the preferences of the citizenry than others (Dalton 1985; Miller and Stokes 1963). One possible reason for this cross-national variation is that some political institutions make for more congruent governments than others. In particular, an "ideological congruence controversy" (Powell 2009) has emerged regarding the role of electoral systems in promoting mass-elite congruence. The scholarly debate is between those who find that electoral systems of proportional representation generate more mass-elite ideological congruence than majoritarian electoral systems (Ezrow 2007; Huber and Powell 1994; Powell 2006, 2009, 2013) and those who find no difference across electoral systems (Blais and Bodet 2006; Golder and Lloyd 2014; Golder and Stramski 2010).

Another set of congruence debates has emerged with specific focus on the United States. A recent wave of studies there point to a wide-and perhaps widening-gap between voter preferences and the policymaking choices of elected officials (Bartels 2008; Gilens 2005, 2011, 2012). Instead of treating all citizens' - or even all voters'-preferences equally, the democratic process in the United States appears to privilege the preferences of the very affluent voters over all others. Still, other studies maintain that US elites are not more responsive to the preferences of the affluent (Bhatti and Erikson 2011; Wlezien and Soroka 2011).

Both sets of debates focus exclusively on advanced democracies. Only very few scholars have studied mass-elite congruence in developing democracies, and their findings do not speak directly to these broader debates. In Eastern Europe and Latin America, these studies find considerable mass-elite congruence in the stated preferences of citizens and elites (Kitschelt et al. 1999, 2010; Luna and Zechmeister 2005; Miller et al. 1995, 1997, 1998; Saiegh 2015; Siavelis 2009). But they also find considerable heterogeneity: Luna and Zechmeister (2005), for instance, 
find higher levels of mass-elite congruence in more consolidated party systems and among parties of the left.

Even these studies, however-like the studies of advanced democracies that are part of the ideological congruence controversy-focus entirely on left-right ideological positions. As a result, they rely on citizens' self-placements on a left-right ideological continuum, even though we know that these survey items generate high levels of (non-random) nonresponse and that ideological labels can mean different things in different contexts (Zechmeister 2006; Zechmeister and Corral 2013). ${ }^{2}$ As Golder and Stramski (2010) note, many of these studies often also simply compare the mean responses of citizens and elites, paying no attention to the distribution of responses. This can be misleading: the mean response may in fact reflect the preference of very few voters. ${ }^{3}$ And these studies also fail to distinguish among different types of voters or different types of issue areas in ways that might speak to the debate over unequal representation.

In this chapter, we extend the study of mass-elite congruence by focusing on a developing democracy, employing more sophisticated methods of measuring congruence, and disaggregating congruence along different issue dimensions and different subgroups of citizens and elites. We focus on the case of Argentina and use a unique survey of both elites and citizens conducted in 2014. And we compare the entire distribution of responses between elites and the public rather than just mean responses.

We find that mass-elite congruence in Argentina is fairly high, although there is considerable variation across issue areas. We also find that on most issues, Argentine elites' preferences more closely resemble those of citizens residing in Greater Buenos Aires, those who identify with the ruling political parties, and the most affluent. In other words, we find a distinct elite bias toward the capital, government supporters, and the wealthy. We also find that elites in the executive branch are more congruent with mass preferences than those in the legislature, perhaps because of their more national voter base.

\section{Data, Measurement, and Estimation}

Our empirical strategy extends the study of mass-elite congruence in three ways. First, while previous research has mostly focused on self-placement on a left-right ideological scale-which we replicate here-we also study congruence on specific questions of normative and policy importance. Second, while previous research on congruence has often relied on 
comparing survey responses against observed policy outcomes, we avoid the problems implicit in this approach by directly examining preferences of both citizens and elites. Finally, we use a unique survey that makes such straightforward comparisons feasible.

Our data consist of 140 Argentine elites and 1,200 citizens surveyed in April 2014. Among the elite respondents, 94 held legislative office and 46 held executive office, including mayors, ministers, and governors. ${ }^{4}$ Both samples were asked some 80 identically worded questions, from which we selected a subset that represent important electoral issues and demonstrate the range of variation in congruence.

Of course, by comparing responses in mass and elite surveys, we are limiting our analysis to mass-elite congruence in terms of stated preferences. In the absence of reliable cross-national measures of policy output from developing contexts, prior studies of congruence in the developing world have done the same. The Europe- and US-focused debates have instead compared mass preferences to aggregate measures of policy outcomes or legislative behavior. Our reliance on surveys means that we cannot know whether congruent survey responses between citizens and elites actually translate into policies. This is a limitation that can only be addressed with further scholarly efforts to code policy outputs in developing democracies like Argentina. One might also be concerned that elites responded to the survey strategically, offering not their personal preferences but what they think their constituents want to hear. But if this were the case, then we would see little variation in congruence across issues and we would not find systematic differences in elites' congruence with particular subgroups of citizens. The fact that we do suggests that many elites did respond sincerely to the survey.

Our analysis focuses first on a set of four issue dimensions that are typically salient in developing democracies. Following the debate over ideological congruence, we begin by comparing citizens' and elites' selfplacement on a left-right ideological scale. ${ }^{5}$ But we are also interested in measuring congruence using preferences over more specific sets of issues. In developing democracies, and particularly in Latin America, the issue of democratic regime support is always prominent. We therefore compare citizens' and elites' support for democracy. ${ }^{6}$ In crisis-prone economies like Argentina's, economic policy issues also loom large. To measure economic preferences with minimal measurement error, we combine multiple survey items on salient economic policies into a factored index. ${ }^{7}$ We also use a unique item that asked respondents about their ideal society and the role 
of the state in providing a social safety net. ${ }^{8}$ Finally, populist tendencies are common in developing democracies and especially in Latin America (Conniff 1982; Doyle 2011; Hawkins 2010). The concept is difficult to capture in a single survey item, so we again develop a factored index that combines multiple items similar to the standard measures used by other scholars (Akkerman et al. 2014; Seligson 2007). ${ }^{9}$

Another set of issues is somewhat more specific to the Argentine context. Given rising crime rates in recent years, the perceived trade-off between security and civil liberties has become a salient issue. ${ }^{10}$ Bargaining between the federal government and the governments of individual provinces is also a perennial issue in Argentina, where revenue-sharing arrangements have to be negotiated at regular intervals (Diaz-Cayeros 2006). We therefore examine a question that asks respondents their views on the relative distribution of power between the central and provincial governments. ${ }^{11}$ Finally, we study the policy priorities of citizens and elites by comparing their responses to a standard question about the most important problem facing the country. ${ }^{12}$

Scholars have proposed a variety of methods for calculating congruence between citizens and elites using data like ours. Early research focused on measures such as ideological distance between each district's representative and citizens represented-what Golder and Stramski (2010) call many-to-one congruence. As Achen (1978) argues, however, mean proximity is a poor measure of congruence: legislators in more sharply divided districts will appear further from their average constituent no matter what policy position they take. More generally, such measures do not fully capture the conceptual definition of representation. Proximity will be greatest where representatives are closest to the preferences of the majority within each district, but in aggregating across districts, substantial minorities may not get represented, particularly in single-member district electoral systems. This result contrasts sharply with classical theories of representative government, in which minority groups' voices are a key component (Mill 1859; Pitkin 1967).

These concerns have prompted scholars to instead study many-to-many congruence, or comparisons across distributions of responses. Miller and Stokes (1963), for instance, correlate the distributions of citizen and elite responses to survey questions. But Achen (1977) notes that these measures too are uninformative, because they reflect the variance of each response distribution, not correlations across them. More recently, Golder and Stramski (2010) propose measuring the difference between cumulative distribution 
functions (CDFs), a quantity which they argue most directly captures the outcome of interest for many normative theories of representation.

We begin this chapter by analyzing mass-elite congruence in Argentina with a measure of many-to-many congruence that is similar to Golder and Stramski's. Rather than relying on the CDFs of mass and elite positions, we follow Andeweg (2011) in calculating instead the overlap in probability density functions (PDFs). This approach allows us to compute differences between entire distributions of preferences, which better captures congruence as a concept than does comparing mean or median preferences (Buquet and Selios (Chap. 8), this volume; Golder and Stramski 2010). Additionally, studying PDFs instead of CDFs allows for a more natural interpretation of our results. At no overlap, the dependent variable equals zero; since each PDF sums to unity, complete overlap takes on the value one. This measure of congruence is constrained to the unit interval, and thus predicted effects directly capture changes in percentage points (Andeweg 2011), with positive values indicating more congruence. ${ }^{13}$ Figure 12.1 illustrates how these distributions and overlap look visually for our first dependent variable, self-placement on a $0-10$ ideological scale. ${ }^{14}$

Our analysis allows us to measure the degree of mass-elite congruence in Argentina on the issues outlined above, and to compare congruence across different issues. We also examine whether our measure of congruence is higher for more affluent citizens than the poor, and whether citizens have more congruence with the executive branch than with the legislature.

This analysis, however, is largely impressionistic. We cannot say with any certainty whether our estimates of mass-elite congruence differ in statistically significant ways among different groups of citizens or elites. To do that, we turn to a different technique that allows us to relate individual mass respondents to individual elites (see also Boas and Smith 2014). With dyadic analysis, we can model all possible one-to-one comparisons and better explain variation in the quality of representation for individual Argentines. Dyadic analysis is very common in studies of international relations and conflict, where each state is related to every other state in the international system (see Erikson et al. 2014). For each issue dimension, our analysis measures the distance between each mass respondent and each elite respondent, ${ }^{15}$ then regresses these distances on mass and elite individual characteristics. ${ }^{16}$ 


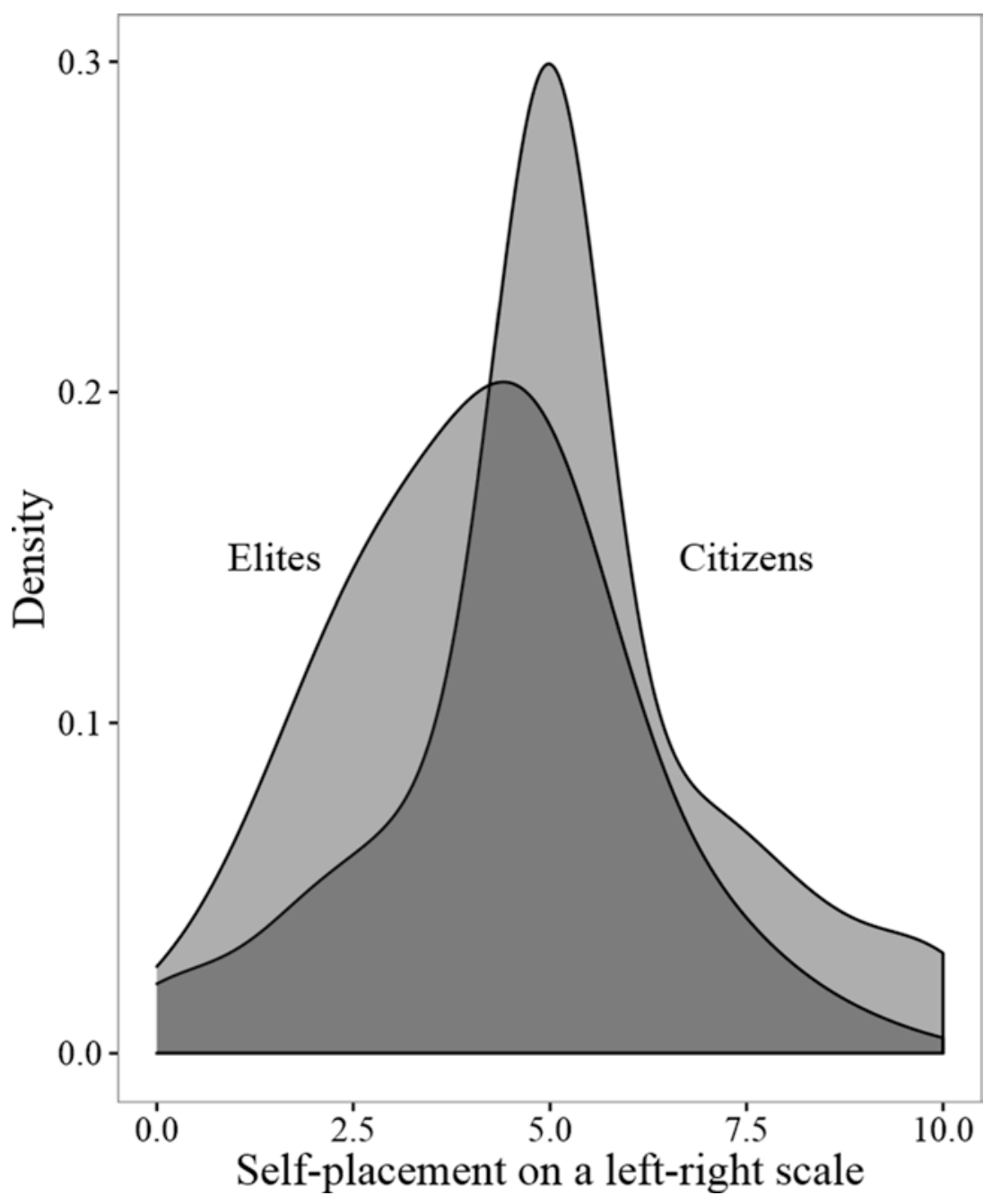

Fig. 12.1 Example of congruence calculation (Notes: Plot compares the densities of self-placements by Argentine citizens and elites on the left-right ideological scale $(0-10)$. The dark gray region represents the overlap between the two densities. Our measure of congruence reports the proportion of the total density that this overlap region represents) 
We focus our analysis on a particular set of citizen and elite characteristics that may condition mass-elite congruence. We expect that elites' policy preferences are closer to those of Argentines who live in Greater Buenos Aires (GBA), a common complaint of citizens who live in the country's interior. We also expect that the preferences of elites from the ruling Frente Para la Victoria (FPV) faction of the Peronist Party are more similar to citizens', given their electoral success and their dominance of the executive branch. Following the debate over unequal representation in the United States, we examine whether elite preferences are closer to those of citizens in a particular social class group. We measure class using the census-based classification of households into socioeconomic status (SES) groups. ${ }^{17}$ Finally, we expect that elites who hold executive positions, and therefore a national constituency, have preferences closer to citizens than do legislative elites, who have more particularistic constituencies. Our models therefore include indicator variables for citizens' GBA residency, partisanship, and social class, as well as elites' branch of government and partisanship. All of our models also include controls for citizen age and gender.

\section{Discussion}

We begin by estimating mass-elite congruence along the issue dimensions we identified. The second column of Table 12.1 reports our congruence measure for each of the issues. In general, the overlap in the distributions

Table 12.1 Mass-elite congruence in Argentina

\begin{tabular}{llllll}
\hline Issue & $\begin{array}{l}\text { All } \\
\text { respondents }\end{array}$ & $\begin{array}{l}\text { High SES } \\
\text { respondents }\end{array}$ & $\begin{array}{l}\text { Low SES } \\
\text { respondents }\end{array}$ & $\begin{array}{l}\text { Executive } \\
\text { elites }\end{array}$ & $\begin{array}{l}\text { Legislative } \\
\text { elites }\end{array}$ \\
\hline Ideology & 0.70 & 0.64 & 0.69 & 0.69 & 0.69 \\
Democracy & 0.79 & 0.86 & 0.77 & 0.85 & 0.75 \\
Economic policy & 0.71 & 0.78 & 0.68 & 0.70 & 0.71 \\
Ideal society & 0.89 & 0.90 & 0.91 & 0.85 & 0.90 \\
Populism & 0.60 & 0.69 & 0.54 & 0.74 & 0.53 \\
Order versus liberty & 0.56 & 0.83 & 0.51 & 0.57 & 0.55 \\
Decentralization & 0.85 & 0.78 & 0.83 & 0.82 & 0.85 \\
Most important & 0.59 & 0.60 & 0.56 & 0.56 & 0.56 \\
problem & & & & &
\end{tabular}

Notes: Values represent calculations of many-to-many congruence in mass and elite responses to particular survey questions 
of mass and elite responses is fairly high, consistent with prior work on the region (Kitschelt et al. 2010; Luna and Zechmeister 2005; Saiegh 2015). But the estimates in Table 12.1 also reveal substantial differences across issues. Citizens and elites seem to agree a lot on their preferences about an ideal society and decentralization, but substantially less on the trade-off between order and civil liberties and the country's most important problem. ${ }^{18}$

We also find remarkable differences in the congruence between elite preferences and those of citizens from different social classes. The third and fourth columns in Table 12.1 report elite congruence with high and low SES respondents, respectively. In some cases-like left-right ideology, preferences about an ideal society, and the most important problemthere is little difference between elites' congruence with high and low SES citizens. But on other issues-like economic policy, populism, and especially the trade-off between order and civil liberties-congruence diverges substantially by citizen social class. ${ }^{19}$ In every case where this occurs, it favors high SES citizens. In other words, elites seem either to share the preferences of all citizens or to hold preferences much more in line with those of affluent citizens.

On the elite side, we find little difference in elites' congruence with citizens between the legislative and executive branches of government. The fifth and sixth columns of Table 12.1 report the congruence measure for each subgroup of elites and show little substantial difference between them. The exception is the case of populism, in which the executive branch seems much more congruent with citizens' preferences than the legislature. But this is unsurprising: these questions ask respondents whether policymaking should be centralized in the executive, with little or no check from other branches of government. Although many citizens may support such populist political tendencies, it is unsurprising that legislators would think differently about their own political agency.

Still, the results in Table 12.1 only provide a coarse understanding of the differences in congruence among different subgroups of citizens and elites. To more rigorously estimate the size and significance of these differences, we turn to our dyadic analysis, reported in Fig. 12.2. In the interest of tractability, we present the analysis for only the five most important issue areas and note that the others look very similar. In addition to more rigorously testing social class differences, the dyadic analysis allows us to also study regional and partisan effects.

Figure 12.2 shows that in Argentina, elites' preferences are systematically more congruent with some citizens than with others. ${ }^{20}$ First, some 


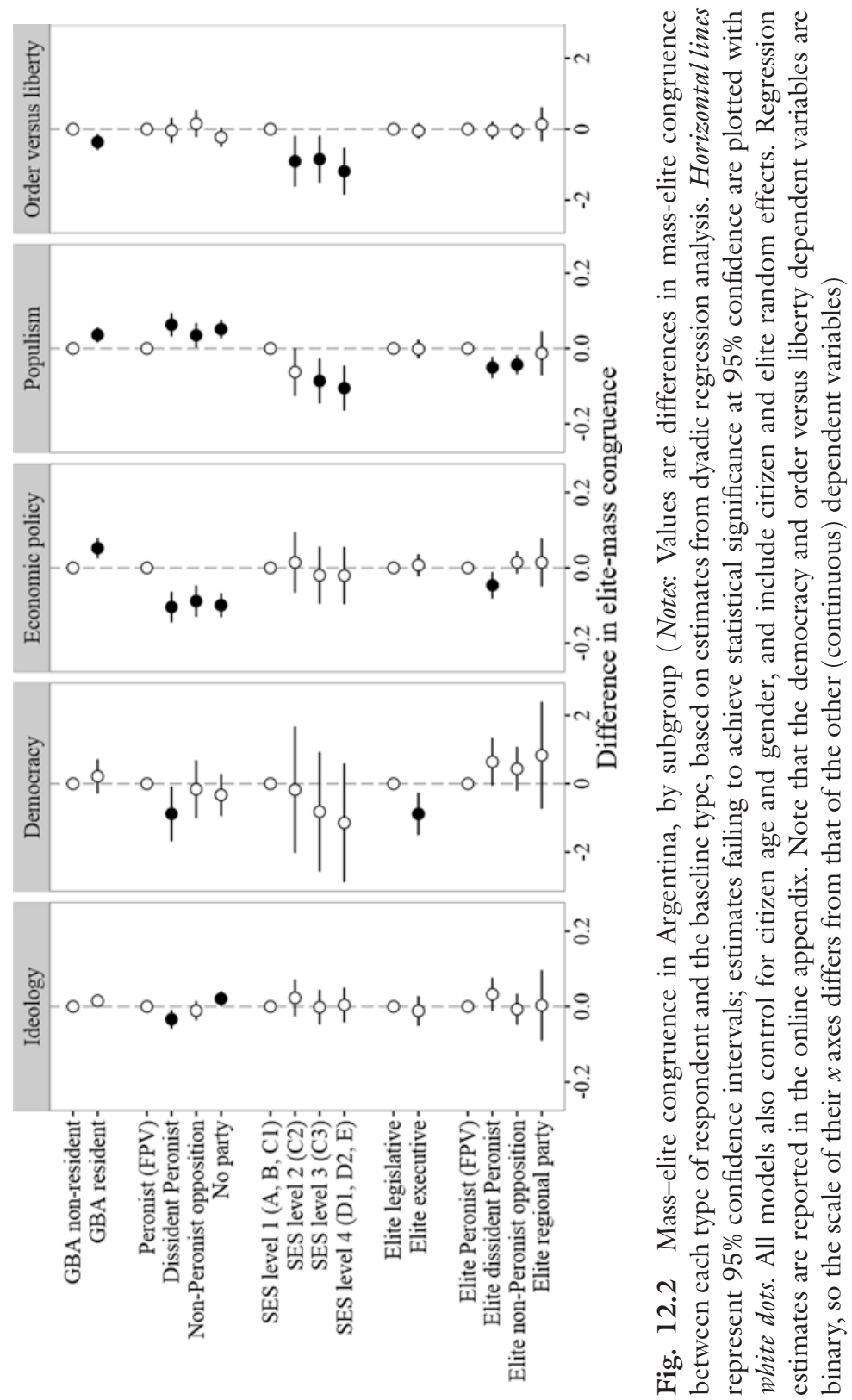


elite preferences seem to mirror more closely the preferences of citizens living in or near the capital. This is particularly the case with economic policy and populism; even with regard to ideology and support for democracy, our estimates suggest some bias toward capital residents, though they are not statistically significant. This may reflect the socialization of political elites who live and form social networks within the capital. The one issue on which elite preferences are biased toward Argentines in the country's interior is the trade-off between order and civil liberties. This is perhaps unsurprising given that crime is a far more pressing issue for citizens living in GBA than elsewhere in the country.

Partisanship also seems to be a source of bias in mass-elite congruence. Citizens who identify with parties in the opposition express preferences that are systematically less well-reflected in the preference distribution of the ruling elite. This would be unsurprising in the context of strong and stable parties, where parties may have incentives to be responsive to their base rather than to the broader electorate (Ezrow et al. 2011). But the Argentine party system has become far more fluid in the last two decades, with the collapse of the Radical Party and the intense factionalization of the Peronist Party (Lupu 2014, 2016). This makes it far more surprising that the ruling party is substantially more congruent with its partisan base than with the rest of the electorate. The one issue on which elites do not favor FPV partisans is populism. In general, mass-elite congruence on this issue is relatively low (Table 12.1), but elite opinion seems to better reflect the preferences of opposition supporters. This may be because legislative elites are simply less likely to hold populist preferences, since these imply granting more political authority and legitimacy to the president. Mass opposition supporters may also be less likely to hold these views since they do not support the president, and this may explain their apparent congruence with elites.

Elite preferences also seem to skew toward the opinions of the more affluent in Argentina. Like studies that find unequal representation in the United States, we find that on certain issues, mass-elite congruence is higher with affluent citizens (SES level 1) than with the poor (SES level 4). This is particularly surprising given that the majority of the elites in our sample belong to the ruling (Kirchnerist) faction of the Peronist Party, which has for a long time attracted a disproportionate share of its support from working-class Argentines (Lupu and Stokes 2009; Tagina 2012). The fact that its members seem to more closely reflect the preferences of affluent Argentines makes it puzzling that they nevertheless continue to win over poor voters. ${ }^{21}$ 
This class bias appears on almost every issue, although it only reaches statistical significance with respect to populism and the trade-off between order and civil liberties. Looking only at Fig. 12.2, there could be two explanations for why we fail to find a similar bias on the other issues. One reassuring possibility is that on these issues-ideology, support for democracy, and economic policy-elite preferences better reflect those of citizens. But another, more sobering possibility, is that citizens from different social classes largely agree on these issues. Figure 12.3 examines

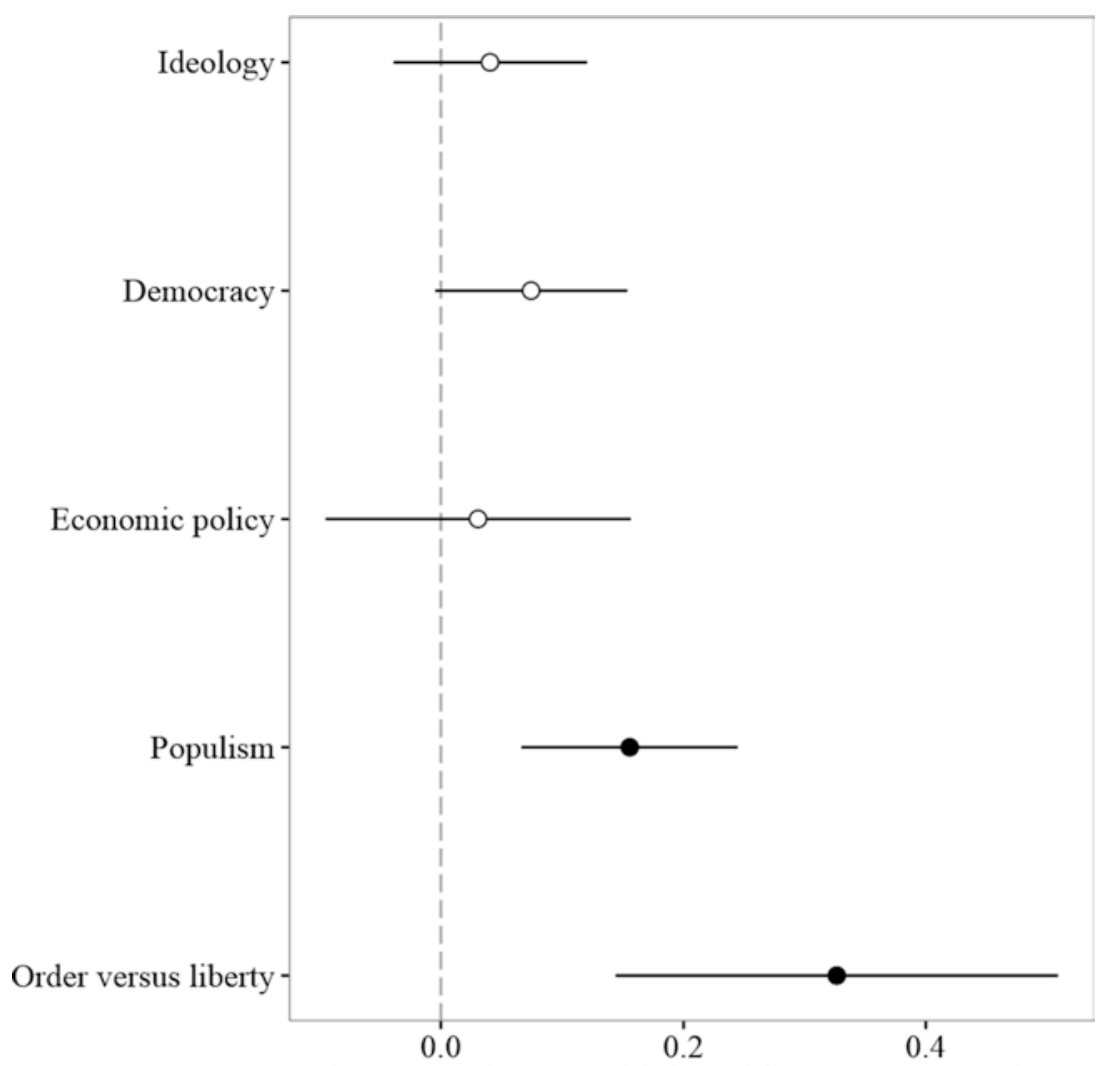

Divergence between high and low SES respondents

Fig. 12.3 Differences in mass preferences, by social class (Notes: Values represent the average difference between mass respondents with high and low SES in responses to survey question on each area. Lines represent the $95 \%$ confidence interval around the estimated difference. White dots represent those estimates that are not statistically significant at the $95 \%$ level. Regression estimates are reported in the online appendix) 
the latter possibility. As it turns out, across social classes, Argentines seem to basically agree when it comes to ideology, support for democracy, and economic policy. As a result, elite preferences correspond as much to the views of the affluent as they do with the preferences of the poor. But when the poor and rich disagree-on populism and the trade-off between order and civil liberties-political elites seem to side with the most affluent. ${ }^{22}$

These results are also substantively important. Elite preferences on economic policy are associated with a 5.2 percentage point increase in congruence for a Buenos Aires resident over an otherwise identical nonresident. Since predicted congruence for non-residents on this issue is 0.65 , this translates into preferences that are $8 \%$ closer to citizens living in the capital, all else equal. The effect of partisanship is even larger: for dissident Peronists, elites are 5\% less congruent on ideology, $7 \%$ on democracy, and $16 \%$ on economic policy. Finally, the largest substantive effect is that of class bias. On the populism issue dimension, members of the lowest SES have preferences 13\% less congruent than those of the highest SES. And on the question of order versus liberty-which is a binary dependent variable-the predicted probability of holding preferences congruent with those of the elite increases from $38 \%$ among the poorest to $66 \%$ among the richest. In other words, elites are $175 \%$ more likely to answer the ordersecurity trade-off in the manner favored by the highest-SES voters. ${ }^{23}$

Why might this be? Why do Argentine politicians hold views that disproportionately represent the rich? One explanation is that campaign contributions tend to come from affluent citizens, making politicians more responsive to the preferences of the rich (Gilens 2012). Another is that the vast majority of Argentine politicians come from affluent backgrounds that skew their preferences toward this social group (Carnes and Lupu 2015). ${ }^{24}$ This suggests that class background contributes to pro-rich bias. Whatever the reason, the preferences of Argentine politicians seem to better reflect those of affluent Argentines. It appears that US elites are not alone in catering to the preferences of the rich.

\section{Mass-Elite Congruence in Argentina and the Malaise of Representation}

Argentine citizens and elites appear to share many of the same preferences when it comes to major issue areas. By our estimation, mass-elite congruence is fairly high in Argentina and comparable to levels seen in Chile and Uruguay (see Buquet and Selios (Chap. 8), this volume; Siavelis (Chap. 4), this volume). But levels of congruence in Argentina vary across issues; in particular, elites seem to reflect public preferences worst when it comes 
to issues related to crime and security, a major preoccupation of citizens in Argentina and across Latin America (Pérez 2015). Moreover, elite preferences seem to correspond much more closely with those of some citizens than with others. Elites seem to skew toward citizens who live in or around the capital, government supporters, and the affluent. Even in a fluid party system, elite preferences seem to skew toward the views of their partisan followers. And even amidst a government disproportionately supported by poor voters, elites' views appear closer to those of the affluent.

Studies of congruence and representation have so far focused primarily on left-right ideology within the advanced democracies. This chapter suggests that many of the same theories can and should be extended to the developing world. Consistent with prior studies, our analysis reveals fairly high levels of congruence in Argentina, which uses proportional representation. But our analysis of issue areas beyond left-right ideology demonstrates that our conclusions about congruence can vary substantially. Our findings also suggest that the class biases in representation that US scholars have recently uncovered may exist elsewhere in the world. This is surely a topic that comparative scholars ought to study further.

To what extent does mass-elite congruence help to explain Argentines' disaffection with democracy? This question is difficult to answer in the absence of data on how individuals perceive their congruence with their elected representatives. But our results do bear indirectly on the question. If a lack of congruence delegitimizes democratic institutions and causes disaffection, then our findings suggest that it should be Argentina's poor, opposition supporters, and interior residents who feel least represented. Heredia and Lorenc (Chap. 11, this volume) report that opposition supporters indeed seem to feel most disaffected, but they find no social class effects (their analysis does not include a variable for GBA residence). Argentines may be politically disaffected because their preferences are poorly represented among the political elite-or others' are disproportionately better represented-but this does not seem to be the major reason.

This does not mean that the patterns of mass-elite congruence are irrelevant. To the contrary, our findings in this chapter show that a fundamental premise of representative democracy seems to be failing specific subgroups of citizens. And it seems to be failing all Argentines on certain issues, especially when it comes to rising crime levels. The fact that very similar representational biases seem to be present in the United States suggests that this is not a fluke specific to Argentina, to this particular time period, or to our particular dataset. Instead, there seems to be something about representative democracy that systematically privileges some citizens over others. 


\section{Notes}

1. For a review of this literature, see Canes-Wrone (2015).

2. Saiegh (2015) addresses some of the problems in comparing ideological spaces across citizens and elites.

3. For instance, in a polarized society in which the distribution of preferences is bimodal, the mean response will be in the center even if no voters actually hold a centrist view. We elaborate on these measurement issues below.

4. The survey initially went into the field in late 2013 , but an election in November and the December-March legislative recess delayed data collection. Thus, 14 respondents in our sample were former legislators and executive office-holders by the time they took the survey. Note also that while the sample of national legislators is representative, the executive branch sample is not. We include a dummy variable for executive elites in our models, which should reduce bias arising from this non-representativeness. Further, limiting our analysis to just the representative sample of legislators does not change any of our substantive results (see online appendix).

5. The question asked, "On a scale from 0 to 10 , where 0 means furthest left and 10 means furthest right, where would you place yourself?" Saiegh (2015) suggests rescaling to account for measurement problems with such questions. This process relies on respondents also placing well-known politicians on the same ideological continuum, which our survey did not include. We therefore cannot rule out measurement problems from variations in how individuals perceive the ideological scales. Still, we are reassured by the question's concrete endpoint labels ("furthest left" and "furthest right"), which are known to help reduce bias (King et al. 2004). Additionally, we can rule out two other types of measurement error that rescaling eliminates-cross-national comparisons and disjoint choices-since they are not relevant to our data.

6. A version of the standard democracy question, the item asked, "With which of the following statements do you agree most strongly? (1) Democracy is preferable to any other form of government; (2) In some circumstances, an authoritarian government can be preferable to a democratic one; or (3) For people like me, a democratic regime means the same thing as an authoritarian one." 
7. The economic policy index was composed of four questions: "Do you agree or disagree with the following statements: (1) It was better when pensions were managed by the AFJP [Administrators of Retirement and Pension Funds, private companies that managed government retirement plans]; (2) It is bad that the state subsidizes electricity, gas, and water-everyone should pay for whatever they consume; (3) Aerolíneas Argentinas should continue being run by the state; and (4) It is good that the state charges taxes on soy exports." The eigenvalue is 1.42 and the factor loadings are -0.33 , $-0.23,0.77$, and 0.82 , respectively.

8. The question asked, "If you could choose the society in which you would want to live, which would you choose? (1) A society in which individual effort (merit) is rewarded; (2) A society in which the rights of all are equally guaranteed; or (3) A society in which the majority win and some lose."

9. The populism index was also composed of four questions: "On a scale from 0 to 10 , where 0 means strongly disagree and 10 means you strongly agree, how much do you agree or disagree with the following statements: (1) When Congress rejects the president's proposals, the president should govern without Congress; (2) On important decisions, the president should consult with the citizenry; (3) The president should have the power to annul a decision of the judiciary; (4) The Supreme Court can limit the decisions of the president." The eigenvalue is 1.47 and the factor loadings are $0.84,-0.13,0.83$, and -0.24 , respectively.

10. The question asked, "If you had the option to choose the government, would you prefer one that guarantees order or individual liberties? (1) A government that solves problems quickly without asking the people their opinion; or (2) A government that takes longer to solve problems but asks the people their opinion."

11. The question asked, "On a scale from 0 to 10 , where 0 means strongly disagree and 10 means you strongly agree, how much do you agree or disagree with the following statement: the provinces should have more authority to manage their own affairs."

12. The question was worded, "Which of the following items do you believe is the country's most important problem? (1) Education; (2) Crime; (3) Health; (4) Pensions; (5) Housing; (6) Other public works such as roads, ports, bridges, etc.; (7) Deterioration of 
the environment; (8) Public transport; (9) Justice; (10) Unemployment; (11) Inflation; (12) Politics; (13) Corruption; (14) Inequality; or (15) Discrimination."

13. The CDF approach also forces scholars to make ad hoc adjustments to the dependent variable. For instance, overlap can range from 0 to 1 for each point at which question responses are evaluated. This means that if all respondents choose the minimum value, overlap will be 11 for a question with a $0-10$ scale, but only 2 for a $0-1$ scale, despite identical responses in each case. This forces us to rescale the dependent variable by question. Moreover, for survey responses that cannot be meaningfully ordered (e.g., "which of these..."), we cannot compute CDFs.

14. Formally, we compute congruence as

$$
y_{c, e, q}=\int_{w}^{W} \min \left\{f_{c, e, q}^{\mathcal{C}}(w), f_{c, e, q}^{\varepsilon}(w)\right\},
$$

where $f^{\mathcal{C}}$ and $f^{\mathcal{E}}$ are empirical PDFs for citizens and elites, respectively, $w$ indexes the possible responses to question $q, c$ and $e$ index citizen and elite subsets of the sample, and there are $c \times e \times q=N$ comparisons.

15. We rescale these distances so that they are constrained to the unit interval, which allows us to directly compare estimated coefficients across issues.

16. Since dyads are non-independent, conventional OLS estimation will produce overly confident standard errors (Erikson et al. 2014). To account for this complication, we conservatively estimate models with random effects for each citizen and each elite. Aronow et al. (2015) provide a cluster-robust variance estimator that relies on weaker assumptions than does a random effects model. However, their approach is not implementable here, since their method assumes dyads are components of a single sample, while ours are drawn from two samples (citizens and elites). We are reassured by the fact that the authors' simulations suggest that random effects models perform well in the absence of misspecification. Each model is specified as

$$
y_{i j}=\beta X_{i j}+\alpha_{i}+\alpha_{j}+\varepsilon_{i j}
$$


where $y_{i j}$ is a dependent variable in Table $12.1, X_{i j}$ is the vector of covariates outlined below, the random effects for citizens and elites are $\alpha_{i} \sim \mathcal{N}\left(0, \sigma_{\alpha_{i}}^{2}\right)$ and $\alpha_{j} \sim \mathcal{N}\left(0, \sigma_{\alpha_{j}}^{2}\right), \quad$ respectively, and $\varepsilon_{i j} \sim \mathcal{N}\left(0, \sigma^{2}\right)$ is idiosyncratic error. These models are computationally intense, and hypothesis testing is non-trivial. We therefore also estimated equivalent models in a fully Bayesian framework, using weakly informative priors (following Gelman et al. 2008). These results are very similar and can be found in the online appendix.

17. Socioeconomic status indexes can be fairly opaque and are therefore not our ideal measure (Lupu 2010). Our ideal would have been a classification of respondent occupation, but that information was not asked in these surveys.

18. As in Uruguay and Chile (see Buquet and Selios (Chap. 8), this volume; Siavelis (Chap. 4), this volume), citizens appear to be much more concerned about crime and security than elites: $35 \%$ of citizens reported crime as the country's primary problem, compared to only $8 \%$ of elites. The most common responses to this question among elites were inequality (34\%) and education (19\%).

19. Regarding the trade-off between order and civil liberties, elites and affluent citizens were much more concerned about civil liberties than poorer citizens: $76 \%$ of elites and $63 \%$ of highest-SES citizens preferred liberties, compared to only $41 \%$ of those of SES level 2, $43 \%$ of SES level 3 , and $34 \%$ of SES level 4 .

20. On the elite side, we find no systematic differences in mass-elite congruence on the basis of elites' partisan affiliation or branch of government.

21. Of course, poor Argentines may not base their ballot choices on policy preferences alone (see Carlin et al. 2015). They may instead choose candidates or parties on the basis of performance evaluations (Lupu 2016; Stokes 2001) or clientelist goods (Stokes et al. 2013).

22. Gilens (2012) demonstrates a similar dynamic in the United States: overall policy responsiveness seems not to have a particular class bias, but on issues on which the poor and the affluent disagree, policy skews significantly toward the preferences of the rich.

23. These computations hold all other covariates not of interest at their central tendency. 
24. Reestimating the dyadic models with elites' parents' and grandparents' education levels (see online appendix), we find that elites from affluent backgrounds express preferences less congruent with those of the public, but only on economic policy.

\section{REFERENCES}

Achen, Christopher H. 1977. Measuring representation: Perils of the correlation coefficient. American Journal of Political Science 21(4): 805-815.

- 1978. Measuring representation. American Journal of Political Science 22(3): 475-510.

Akkerman, Agnes, Cas Mudde, and Andrej Zaslove. 2014. How populist are the people? Measuring populist attitudes in voters. Comparative Political Studies 47(9): 1324-1353.

Andeweg, Rudy B. 2011. Approaching perfect policy congruence: Measurement, development, and relevance for political representation. In How democracy works: Political representation and policy congruence in modern societies, ed. Martin Rosema, Bas Denters, and Kees Aarts. Amsterdam: Amsterdam University Press.

Aronow, Peter M., Cyrus Samii, and Valentina A. Assenova. 2015. Cluster-robust variance estimation for dyadic data. Political Analysis 23(4): 564-577.

Bartels, Larry M. 2008. Unequal democracy: The political economy of the new gilded age. Princeton: Princeton University Press.

Bhatti, Yosef, and Robert S. Erikson. 2011. How poorly are the poor represented in the U.S. Senate? In Who gets represented, ed. Peter K. Enns, and Christopher Wlezien, 223-246. New York: Russell Sage Foundation.

Blais, André, and Marc André Bodet. 2006. Does proportional representation foster closer congruence between citizens and policy makes? Comparative Political Studies 39(10): 1243-1262.

Boas, Taylor C., and Amy Erica Smith. 2014. Looks like me, thinks like me? Descriptive representation and opinion congruence in Brazil. Unpublished manuscript.

Canes-Wrone, Brandice. 2015. From mass preferences to policy. Annual Review of Political Science 18: 147-165.

Carlin, Ryan E., Matthew M. Singer, and Elizabeth J. Zechmeister (ed). 2015. The Latin American voter: Pursuing representation and accountability in challenging contexts. Ann Arbor: University of Michigan Press.

Carnes, Nicholas, and Noam Lupu. 2015. Rethinking the comparative perspective on class and representation: Evidence from Latin America. American Journal of Political Science 59(1): 1-18. 
Conniff, Michael L. (ed). 1982. Latin American populism in comparative perspective. Albuquerque: University of New Mexico Press.

Dalton, Russell J. 1985. Political parties and political representation: Party supporters and party elites in nine nations. Comparative Political Studies 18(3): 267-299.

Diaz-Cayeros, Alberto. 2006. Federalism, fiscal authority, and centralization in Latin America. Cambridge: Cambridge University Press.

Downs, Anthony. 1957. An economic theory of democracy. Boston: Addison Wesley.

Doyle, David. 2011. The legitimacy of political institutions: Explaining contemporary populism in Latin America. Comparative Political Studies 44(11): 1447-1473.

Erikson, Robert S., Pablo M. Pinto, and Kelly T. Rader. 2014. Dyadic analysis in international relations: A cautionary tale. Political Analysis 22: 457-463.

Ezrow, Lawrence. 2007. The variance matters: How party systems represent the preferences of voters. Journal of Politics 69(1): 182-192.

Ezrow, Lawrence, Catherine De Vries, Marco Steenbergen, and Erica Edwards. 2011. Mean voter representation and partisan constituency representation: Do parties respond to the mean voter position or to their supporters? Party Politics 17(3): 275-301.

Ferejohn, John. 1986. Incumbent performance and electoral control. Public Choice 50(1): 5-25.

Gelman, Andrew, Aleks Jakulin, Maria Grazia Pittau, and Su. Yu-Sung. 2008. A weakly informative default prior distribution for logistic and other regression models. The Annals of Applied Statistics 2(4): 1360-1383.

Gilens, Martin. 2005. Inequality and democratic responsiveness. Public Opinion Quarterly 69(5): 778-796.

2011. Policy consequences of representational inequality. In Who gets represented, ed. Peter K. Enns, and Christopher Wlezien, 247-284. New York: Russell Sage Foundation.

- 2012. Affluence and influence: Economic inequality and political power in America. Princeton: Princeton University Press.

Golder, Matt, and Gabriella Lloyd. 2014. Re-evaluating the relationship between electoral rules and ideological congruence. European Journal of Political Research 53: 200-212.

Golder, Matt, and Jacek Stramski. 2010. Ideological congruence and electoral institutions: Conceptualization and measurement. American Journal of Political Science 54(1): 90-106.

Hawkins, Kirk. 2010. Venezuela's chavismo and populism in comparative perspective. Cambridge: Cambridge University Press.

Huber, John D., and G. Bingham Powell. 1994. Congruence between citizens and policymakers in two visions of liberal democracy. World Politics 46(3): 291-326. 
King, Gary, Christopher J.L. Murray, Joshua A. Salomon, and Ajay Tandon. 2004. Enhancing the validity and cross-cultural comparability of measurement in survey research. American Political Science Review 98(1): 191-207.

Kitschelt, Herbert, Kirk Hawkins, Juan Pablo Luna, Guillermo Rosas, and Elizabeth J. Zechmeister. 2010. Latin American party systems. Cambridge: Cambridge University Press.

Kitschelt, Herbert, Zdenka Mansfeldova, Radoslaw Markowski, and Gábor Tóka. 1999. Post-communist part systems: Competition, representation, and inter-party cooperation. Cambridge: Cambridge University Press.

Luna, Juan P., and Elizabeth J. Zechmeister. 2005. Political representation in Latin America: A study of elite-mass congruence in nine countries. Comparative Political Studies 38(4): 388-416.

Lupu, Noam. 2010. Who votes for chavismo? Class voting in Hugo Chávez's Venezuela. Latin American Research Review 45(1): 7-32.

. 2014. Brand dilution and the breakdown of political parties in Latin America. World Politics 66(4): 561-602.

- 2016. Party brands in crisis: Partisanship, brand dilution, and the breakdown of political parties in Latin America. Cambridge: Cambridge University Press.

Lupu, Noam, and Susan C. Stokes. 2009. The social bases of political parties in Argentina, 1912-2003. Latin American Research Review 44(1): 58-87.

Manin, Bernard. 1997. The principles of representative government. Cambridge: Cambridge University Press.

Mill, John Stuart. 1859. On liberty. London: Longman, Roberts, and Green.

Miller, Arthur H., Vicki L. Hesli, and William M. Reisinger. 1995. Comparing citizen and elite belief systems in post-Soviet Russia and Ukraine. Public Opinion Quarterly 59(1): 1-40.

. 1997. Conceptions of democracy among mass and elite in post-Soviet societies. British Journal of Political Science 27(2): 157-190.

Miller, Arthur H., William M. Reisinger, and Vicki L. Hesli. 1998. Establishing representation in post-Soviet societies: Change in mass and elite attitudes toward democracy and the market, 1992-1995. Electoral Studies 17(3): 327-349.

Miller, Warren E., and Donald E. Stokes. 1963. Constituency influence in congress. American Political Science Review 57(1): 45-56.

Pérez, Orlando J. 2015. The impact of crime on voter choice in Latin America. In The Latin American voter: Pursuing representation and accountability in challenging contexts, ed. Ryan E. Carlin, Matthew M. Singer, and Elizabeth J. Zechmeister, 324-345. Ann Arbor: University of Michigan Press.

Pitkin, Hanna Fenichel. 1967. The concept of representation. Berkeley: University of California Press.

Powell, G. Bingham Jr. 2006. Election laws and representative governments: Beyond votes and seats. British Journal of Political Science 36(2): 291-315. 
2009. The ideological congruence controversy: The impact of alternative measures, data, and time periods on the effects of election rules. Comparative Political Studies 42(12): 1475-1497.

- 2013. Representation in context: Election laws and ideological congruence between citizens and governments. Perspectives on Politics 11(1): 9-21.

Saiegh, Sebastián. 2015. Using joint scaling methods to study ideology and representation: Evidence from Latin America. Political Analysis 23: 363-384.

Seligson, Mitchell A. 2007. The rise of populism and the left in Latin America. Journal of Democracy 18(3): 81-95.

Siavelis, Peter. 2009. Elite-mass congruence, partidocracia and the quality of Chilean democracy. Journal of Politics in Latin America 1(3): 3-31.

Stokes, Susan C. 2001. Mandates and democracy: Neoliberalism by surprise in Latin America. Cambridge: Cambridge University Press.

Stokes, Susan C., Thad Dunning, Marcelo Nazareno, and Valeria Brusco. 2013. Brokers, voters, and clientelism. Cambridge: Cambridge University Press.

Tagina, María Laura. 2012. Factores contextuales, predisposiciones de largo plazo y accountabilty electoral en Argentina en tiempos del Kirchnerismo. Politica y Gobierno 19(2): 343-375.

Wlezien, Christopher, and Stuart N. Soroka. 2011. Inequality in policy responsiveness? In Who gets represented, ed. Peter K. Enns, and Christopher Wlezien, 285-310. New York: Russell Sage Foundation.

Zechmeister, Elizabeth. 2006. What's left and who's right? A Q-method study of individual and contextual influences on the meaning of ideological labels. Political Behavior 28(2): 151-173.

Zechmeister, Elizabeth J., and Margarita Corral. 2013. Individual and contextual constraints on ideological labels in Latin America. Comparative Political Studies 46(6): 675-701. 